\title{
Impact of prawn farming effluent on coral reef water nutrients and microorganisms
}

\author{
Cynthia Becker ${ }^{1,2}$, Konrad Hughen ${ }^{1}$, Tracy J. Mincer ${ }^{1}$, Justin Ossolinski ${ }^{1}$, \\ Laura Weber ${ }^{1}$, Amy Apprill ${ }^{1, *}$
}

${ }^{1}$ Department of Marine Chemistry and Geochemistry, Woods Hole Oceanographic Institution, Woods Hole, MA 02543, USA ${ }^{2}$ Department of Biology, Ithaca College, Ithaca, NY 14850, USA

\begin{abstract}
Tropical coral reefs are characterized by low-nutrient waters that support oligotrophic picoplankton over a productive benthic ecosystem. Nutrient-rich effluent released from aquaculture facilities into coral reef environments may potentially upset the balance of these ecosystems by altering picoplankton dynamics. In this study, we examined how effluent from a prawn (Litopenaeus vannamei) farming facility in Al Lith, Saudi Arabia, impacted the inorganic nutrients and prokaryotic picoplankton community in the waters overlying coral reefs in the Red Sea. Across 24 sites, ranging $0-21 \mathrm{~km}$ from the effluent point source, we measured nutrient concentrations, quantified microbial cell abundances, and sequenced bacterial and archaeal small subunit ribosomal RNA (SSU rRNA) genes to examine picoplankton phylogenetic diversity and community composition. Our results demonstrated that sites nearest to the outfall had increased concentrations of phosphate and ammonium and elevated abundances of non-pigmented picoplankton (generally heterotrophic bacteria). Shifts in the composition of the picoplankton community were observed with increasing distance from the effluent canal outfall. Waters within $500 \mathrm{~m}$ of the outfall harbored the most distinct picoplanktonic community and contained putative pathogens within the genus Francisella and order Rickettsiales. While our study suggests that at the time of sampling, the Al Lith aquaculture facility exhibited relatively minor influences on inorganic nutrients and microbial communities, studying the longer-term impacts of the aquaculture effluent on the organisms within the reef will be necessary in order to understand the full extent of the facility's impact on the reef ecosystem.
\end{abstract}

KEY WORDS: Aquaculture - Litopenaeus vannamei - Oligotrophic $\cdot$ Microbial community · Coral reef $\cdot$ SSU rRNA gene $\cdot$ Francisella spp.

\section{INTRODUCTION}

Aquaculture facilities contribute substantially to the world fish supply and are increasing in abundance worldwide (Naylor et al. 2000). In 2014, over half of the fish that humans consumed were produced through aquaculture, highlighting the importance of aquaculture as a reliable food source for increasing populations (FAO 2016). Aquaculture is important, but the wastes and nutrients produced by these facilities can pose threats to coastal environ-

${ }^{*}$ Corresponding author: aapprill@whoi.edu ments (Nogales et al. 2011, Jiang et al. 2013). As a result, monitoring efforts are routinely needed to understand potential impacts. Most aquaculture monitoring efforts are part of required environmental impact assessments that may include collecting measurements of water quality, nutrient concentrations, organic matter outputs, and residual chemicals and bacteria that affect the product quality (Hambrey 2009). In addition, indicator species assays are commonly used to detect a finite number of known pathogens (Hernández et al. 2009, Zhou et al. 2014).

() The authors 2017. Open Access under Creative Commons by Attribution Licence. Use, distribution and reproduction are unrestricted. Authors and original publication must be credited. 
There has been much less effort towards monitoring how entire bacterial and archaeal communities respond to the influx of aquaculture waste. A more inclusive method that uses comparative phylogenetic analyses to examine how picoplanktonic communities respond can help deepen this understanding.

Microorganisms, including Bacteria, Archaea, and phytoplankton, are critical to the coastal marine environment and actively participate in biogeochemical cycling of nutrients and organic matter (Kirchman et al. 2007, DeLong 2009). Microbes are sensitive to eutrophication and pollution-based changes in seawater, with some cells exhibiting enhanced or reduced growth under these conditions (dos Santos et al. 2011, Xiong et al. 2015). Studies have shown that in oligotrophic waters, continual enrichment of nitrate and phosphate alters the native bacterial community composition (Chen et al. 2016, Dong et al. 2017). As a result, microorganisms may be able to serve as sensitive indicators of change, especially in oligotrophic environments where the magnitude of nutrient and organic matter inputs from aquaculture could be much higher than natural inputs to the environment. For example, the naturally oligotrophic coral reef waters of the Red Sea feature very low nutrient concentrations of $0.05-0.1 \mu \mathrm{M}$ phosphate, $<0.1 \mu \mathrm{M}$ ammonium, and $<0.3 \mu \mathrm{M}$ nitrate+nitrite (Furby et al. 2014). Therefore, water-column samples from coral reefs located within the Red Sea are ideal for identifying how anthropogenic inputs from aquaculture facilities perturb the low-nutrient system and impact the bacterial and archaeal picoplankton communities.

Nutrient pollution and eutrophication from aquaculture are important problems affecting tropical coral reef ecosystems that reside in oligotrophic waters. Specifically, aquaculture runoff introduces ammonium, phosphate, and organic solids into the surrounding water. Studies have shown that fish farm runoff can reduce the survivorship of juvenile corals (Villanueva et al. 2005) and impair coral reproduction (Loya et al. 2004), as well as impact coralassociated microbes (Garren et al. 2008, 2009, Campbell et al. 2015). Studies also demonstrate that the planktonic microbial community, which is easier to sample and analyze than coral-associated microbes (e.g. Apprill et al. 2016), shows similar community changes in response to environmental aquaculture pollution (Sousa et al. 2006, Garren et al. 2008, Fodelianakis et al. 2014, Xiong et al. 2015). For example, in aquaculture environments such as a coastal shrimp pond in southeast China (Wei et al. 2009) and a fish farm north of Crete, Greece (Fo- delianakis et al. 2014), the seawater microbial communities had reduced phylogenetic diversity and experienced overall shifts in community composition. Increases in Proteobacteria, free-living bacteria, and virus-like particles were also noted in the oligotrophic reef waters of the Philippines, correlating with organic nutrient enrichment caused by a fish farm (Garren et al. 2008). These often site-specific alterations to the planktonic microbial community by aquaculture speak to the complexity of these oligotrophic ecosystems. It also exemplifies the need for continued assessments of these impacts, especially in understudied areas such as the eastern Red Sea.

The National Aquaculture Group, formerly known as the National Prawn Company, is a coastal aquaculture facility located next to coral reefs in the eastern Red Sea, near the city of Al Lith, Saudi Arabia. It is one of the largest desert aquaculture facilities in the world and covers approximately $250 \mathrm{~km}^{2}$. From 2008 to 2010, our team examined the Red Sea marine environment to identify potential sources of putative pathogens that were associated with the presence of harmful coral lesions (Apprill et al. 2013, Furby et al. 2014). As part of this study, we examined whether the effluent from the National Prawn Company aquaculture facility could be a potential source of nutrients and pathogens to the surrounding environment. At the time of the sampling in 2009, the facility was hatching and rearing approximately 15000 tons of white prawn Litopenaeus vannamei annually in ponds covering a total surface area of 2800 ha (https://web.archive.org/web/20091130220933/http: //www.robian.com.sa:80/home.html; see also www. naqua.com.sa). Since the time of sampling, the facility expanded to include multiple sea cages and many more shrimp farms and produces upwards of 100000 tons of marine products annually, including shrimp, sea cucumber, and sea bass (www.naqua. com.sa). Furthermore, Saudi Arabia has plans to expand its aquaculture industry, with multiple investments in new facilities (Mon Chalil 2015). In the context of continuous expansions of the aquaculture industry, it is important to understand the extent to which this industry may threaten the adjacent delicate reef ecosystem. In this study, we aimed to assess the impact of the effluent from this aquaculture facility on the surrounding oligotrophic reef environment by examining the inorganic nutrient concentrations and microbial communities in an area extending nearly $22 \mathrm{~km}$ from the outfall. We hypothesized that concentrations of inorganic nitrogen and phosphorus would be elevated at the outfall, a distinct microbial community would reside there, including known 

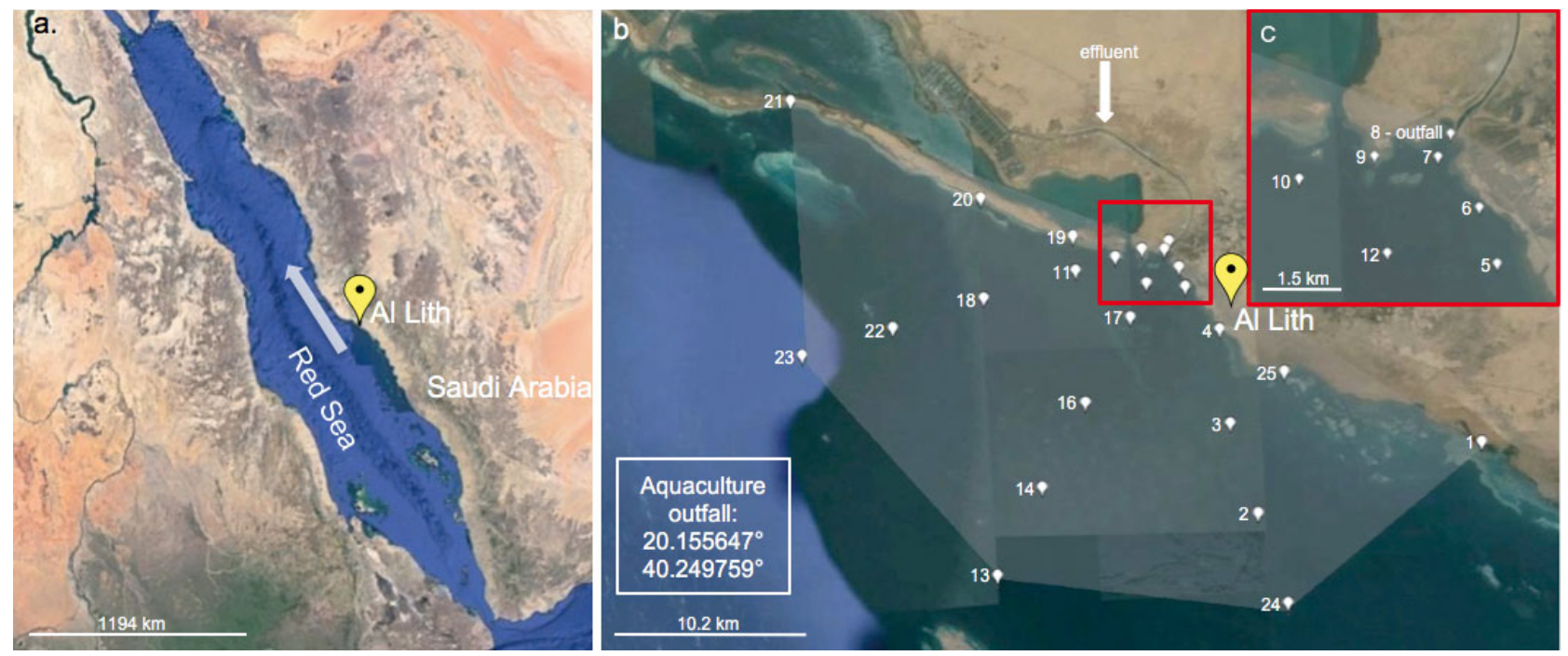

Fig. 1. (a) Location of the aquaculture facility in Al Lith, Saudi Arabia (yellow pin), in the eastern Red Sea. Gray arrow: the prevailing surface currents that move $\mathrm{S}$ to $\mathrm{N}$, primarily along the eastern coast. (b) The 24 sites that were sampled along 5 transects extending from the aquaculture outfall up to $21.7 \mathrm{~km}$ from the outfall. (c) Inset: a more detailed map of the outfall (Site 8) and nearby sites. Images reproduced according to Google permissions and incorporate data from NOAA, US Navy, National

Geospatial-Intelligence Agency, General Bathymetric Chart of the Oceans, DigitalGlobe, and US Geological Survey

pathogens, and that this impact would diminish with increasing distance from the outfall.

\section{MATERIALS AND METHODS}

\section{Sampling}

Sampling occurred in the eastern Red Sea, surrounding the runoff from the National Prawn Company aquaculture facility in Al Lith, Saudi Arabia (Fig. 1a). Seawater was sampled from 24 stations surrounding the aquaculture facility using a directionaltransect grid pattern (Fig. 1b,c) from October 9 to 12, 2009, during 10:00-16:00 h. The sampling pattern extended in 5 transects away from the outfall point source: north, northwest, west, southwest, and south along the coastline (Table A1 in the Appendix). Sampling occurred first at the mouth of the outfall, and then was spaced $0.5-21.7 \mathrm{~km}$ along the 5 transects (Fig. 1). Seawater was sampled at a $10 \mathrm{~m}$ depth, which was just above the coral reef for the shallower sites, into 201 acid-washed carboys. Inorganic nutrients and microbial abundance samples were collected and processed as previously outlined in Furby et al. (2014). Briefly, for inorganic nutrients, $150 \mathrm{ml}$ polypropylene acid-washed bottles were filled with seawater and frozen at $-20^{\circ} \mathrm{C}$. Samples $(1 \mathrm{ml})$ for cell counts were fixed in $1 \%(\mathrm{v}: \mathrm{v})$ paraformaldehyde (final concentration) and placed in cryovials in liquid nitrogen for $3 \mathrm{wk}$, then frozen at $-80^{\circ} \mathrm{C}$. Seawater for DNA analyses was stored on ice for no more than $4 \mathrm{~h}$ before it was filtered onto $0.22 \mu \mathrm{m}$ Durapore membrane filters (142 $\mathrm{mm}$ ) (Millipore) with a peristaltic pump. Filters were then frozen in liquid nitrogen.

\section{Nutrient analysis}

Nutrients were analyzed as outlined in Furby et al. (2014). In summary, dissolved concentrations of $\mathrm{NH}_{4}{ }^{+}, \mathrm{NO}_{3}{ }^{-}+\mathrm{NO}_{2}{ }^{-}, \mathrm{NO}_{2}{ }^{-}, \mathrm{PO}_{4}{ }^{3-}$, and silicate were determined with a continuous segmented flow system including a Technicon AutoAnalyzer II (SEAL Analytical) and an Alpkem RFA 300 Rapid Flow Analyzer. $\mathrm{NO}_{3}{ }^{-}+\mathrm{NO}_{2}{ }^{-}$and $\mathrm{NO}_{2}{ }^{-}$were measured according to Armstrong et al. (1967). An adjusted molybdenum blue method was used to measure $\mathrm{PO}_{4}{ }^{3-}$ (Bernhardt \& Wilhelms 1967). The indophenol blue method was used to measure concentrations of $\mathrm{NH}_{4}{ }^{+}$ (USEPA 1983), and validated using a method developed by Holmes et al. (1999).

\section{Direct cell counts}

Microbial cell counts were enumerated using the flow cytometry methods described in Furby et al. (2014). To summarize, the preserved samples were analyzed using stained and unstained methods to 
determine the number of pigmented and non-pigmented cells within each sample. The aliquots of sample for the unstained method were run on an EPICS ALTRA flow cytometer (Beckman Coulter) to determine abundance of Cyanobacteria (Prochlorococcus and Synechococcus) and small eukaryotic phytoplankton (picoeukaryotes). The aliquot of sample for staining was prepared by diluting the sample 1:10 into a $30 \mathrm{mM}$ (final concentration) potassium citrate buffer solution, and staining with Sybr Green I (1:5000 final dilution of initial stock) (Molecular Probes) for a duration of $2 \mathrm{~h}$ in the dark at $4^{\circ} \mathrm{C}$. Excitation of the fluorescent stain was accomplished using a laser operating at a wavelength of $488 \mathrm{~nm}$ on the same EPICS ALTRA flow cytometer, and this allowed for enumerating picoplankton (Bacteria and Archaea) on the basis of DNA staining (Sybr Green I green fluorescence), chlorophyll, phycoerythrin, forward scatter, and $90^{\circ}$ side scatter signatures. Prochlorococcus cell counts from the unstained method were subtracted from total prokaryotic cells to obtain counts of non-pigmented picoplankton. FlowJo software (v.6.3.3, Tree Star) was used for off-line data analysis.

\section{DNA analysis}

The filters were cut into quarters, and DNA was extracted from one of the quarters using a bead beating method combined with a sucrose-lysis extraction and spin-column separation. Briefly, $0.1 \mathrm{~mm}$ glass beads were used to homogenize cellular biomass collected on the filters for $10 \mathrm{~min}$ in a solution of $875 \mu \mathrm{l}$ sucrose-EDTA lysis buffer (0.75 M sucrose, $20 \mathrm{mM}$ EDTA, $400 \mathrm{mM} \mathrm{NaCl}, 50 \mathrm{mM}$ Tris) and $100 \mathrm{ml}$ of $10 \%$ sodium dodecyl sulfate. This was followed by a Proteinase $\mathrm{K}$ digestion at $55^{\circ} \mathrm{C}$ for $4 \mathrm{~h}$, and separation of the DNA using the spin columns supplied by the DNeasy kit (Qiagen) (Santoro et al. 2010). The DNA samples were individually amplified with the 515F (5-GTG CCA GCM GCC GCG GTA A-3) and 806RB primers (5 -GGA CTA CNV GGG TWT CTA AT-3 ), with the modified reverse primer designed to enhance the detection of different SAR11 clades (Apprill et al. 2015). The primers were designed similar to Kozich et al. (2013) and each included a unique $8 \mathrm{bp}$ barcode, $10 \mathrm{bp}$ pad, and $2 \mathrm{bp}$ link in addition to the primers described above. PCR reactions were carried out in a Bio-Rad thermocycler using triplicate $25 \mu \mathrm{l}$ volumes for each sample. Each reaction included 1.25 U GoTaq Flexi DNA Polymerase (Promega), 5× Colorless GoTaq Flexi Buffer, $2.5 \mathrm{mM}$
$\mathrm{MgCl}_{2}, 200 \mu \mathrm{M}$ dNTP mix (Promega), $200 \mathrm{nM}$ of the corresponding barcoded primer, and 1-4 ng of genomic DNA template. The reaction conditions were as follows: initial denaturation for $2 \mathrm{~min}$ at $95^{\circ} \mathrm{C}$, followed by an iteration of $20 \mathrm{~s}$ at $95^{\circ} \mathrm{C}, 15 \mathrm{~s}$ at $55^{\circ} \mathrm{C}$ and 5 min at $72^{\circ} \mathrm{C}$ for $25-28$ cycles, and a final extension step for $10 \mathrm{~min}$ at $72^{\circ} \mathrm{C}$. Five $\mu$ l of the reaction products were run on a $1 \%$ agarose/TBE gel containing the HyperLadder 50 bp DNA ladder (generally 5 ng $\mu^{-1}$ ) (Bioline). After pooling the triplicate reactions per sample, the PCR products were purified with the QIAquick Purification Kit (Qiagen). The samples were quantified using the Qubit 2.0 Fluorometer with the dsDNA High Sensitivity Assay (Life Technologies). The PCR products were then combined into equimolar ratios and processed for sequencing using $250 \mathrm{bp}$ paired-end MiSeq (Illumina) at the W. M. Keck Center for Comparative and Functional Genomics at the University of Illinois. Raw sequence data were deposited into the National Center for Biotechnology Information (NCBI) Sequence Read Archive (SRA) under accession number PRJNA357506.

\section{Sequence analysis}

Sequence data were filtered and analyzed using mothur v.1.36.1 (Schloss et al. 2009). This included constructing contigs, filtering out long amplicons (over $255 \mathrm{bp}$ ), and removing chimeras detected using de novo UCHIME v.4.2.40 (Edgar et al. 2011). The taxonomic assignment for each sequence was performed in mothur using the SILVA SSU reference database (v.123) and the $k$-nearest neighbor algorithm with an $80 \%$ cutoff. The number of small subunit ribosomal RNA (SSU rRNA) sequences per sample varied between 266 and 55182 and the dataset was therefore subsampled to a depth of 10200 sequences per sample, resulting in the loss of only Sample 20 (Appendix 1). Operational taxonomic units (OTUs) for each sample were generated using the minimum entropy decomposition (MED) clustering algorithm (Eren et al. 2015). MED further reduced the sequence reads to between 8853 and 9538 sequences per sample (Appendix 1).

\section{Graphical and statistical analyses}

Ocean Data View software (v.4.7.8, 64 bit) (Schlitzer 2002) was used to create contour plots of nutrients and microbial abundances using data-interpolating variational analysis (DIVA) gridding $(40 \times 40$ 
scale length). PRIMER-E 7 (v.7.0.11, Quest Research) was used to compare the composition of OTUs at each sampling site. The data were square-root transformed, compared using Bray-Curtis similarity, and plotted using non-metric multidimensional scaling (nMDS) to compare microbial community structure across samples. Information regarding proximity to the outfall was superimposed onto the symbols for each sample in the nMDS plot. In addition, bar plots were generated in Excel for Mac 2011 (v.14.6.9, Microsoft) to illustrate microbial community composition by plotting the relative percent abundance of taxonomic groups of Bacteria and total Archaea.

Alpha diversity metrics of microbial communities at each site were computed using the plot_richness function in the phyloseq (v.1.16.2) and ggplot2 (v.2.1.0) R packages in RStudio (v.0.99.902) (Wickham 2009, McMurdie \& Holmes 2013). Specific metrics plotted include 'observed' (observed richness), 'Chao1' (estimator of richness), and 'invsimpson' (inverse Simpson index of diversity). Differentially abundant OTUs between the outfall and other sites were obtained using DESeq2 (v.1.12.4) in RStudio (Love et al. 2014). Specifically, OTU sequence count data was compared between the outfall site and 6 different distance groups away from the outfall that encompassed the other sites $(0.5-1.5,2.5-3$, 4.5-5.3, 9-10.1, 14.5-15.2, and 20-21.7 km). Significant differential abundance was determined in DESeq2 using the adjusted $p$-value $(p<0.05)$. Box plots of relative abundance data for significantly enriched (at the outfall) OTUs were created in PRIMER-E 7 (v.7.0.11).

\section{RESULTS}

\section{Nutrients}

Nutrient concentrations were generally similar across most of the sites spanning $0-21.7 \mathrm{~km}$ from the outfall (Fig. 2), with the exception of ammonium and phosphate, which were elevated at the outfall by 5-75 times and 4-14 times, respectively, compared to the other sites (Fig. 2a,d). Ammonium was $0.60 \mu \mathrm{M}$ at the outfall and below $0.12 \mu \mathrm{M}$ (Site 19) at all other sites (Fig. 2a,j). The concentration of phosphate at the outfall was the highest measured in the study, at $0.67 \mu \mathrm{M}$, while all other sites were lower, below $0.17 \mu \mathrm{M}$ (Site 7) (Fig. 2d,m). Concentrations of nitrite, nitrate+nitrite, and silicate were not elevated near the outfall, and were similar in concentration to the more distant sites (Fig. 2b,c,e,k,l,n). Over the study area, the combined nitrate+nitrite concentrations ranged from undetectable to $0.87 \mu \mathrm{M}$, nitrite ranged from 0.02 to $0.11 \mu \mathrm{M}$, and silicate ranged from 0.08 to $1.64 \mu \mathrm{M}$ (Fig. 2b,c,e).

\section{Microbial abundances}

Cell counts of microbial groups were measured at all 24 sites (Fig. 2f-i), and there were no clear patterns in cell abundances, either elevated or depleted, directly at the outfall. Concentrations of non-pigmented picoplankton, a proxy for heterotrophic Bacteria, Archaea, and non-pigmented photoheterotrophic Bacteria, were high at the outfall $\left(1.5 \times 10^{6} \mathrm{cells} \mathrm{ml}^{-1}\right)$ as well as at Sites 19,17, 10, and $11\left(1.3\right.$ to $1.5 \times 10^{6}$ cells $\mathrm{ml}^{-1}$ ), which are all between 3 and $5 \mathrm{~km}$ away from the outfall (Fig. 2f,o). Concentrations were up to $9.3 \times 10^{5}$ cells $\mathrm{ml}^{-1}$ lower at the remaining sites, which ranged from $5.8 \times 10^{5}$ to $1.2 \times 10^{6} \mathrm{cells} \mathrm{ml}^{-1}$. Synechococcus spp. were depleted directly at the outfall $\left(1.5 \times 10^{5}\right.$ cells ml $\left.^{-1}\right)$ compared to nearby Sites 7 and 9 that are $\leq 1.5 \mathrm{~km}$ away $\left(2.0-2.1 \times 10^{5}\right.$ cells $\mathrm{ml}^{-1}$ ) (Fig. 2q). Synechococcus spp. were most abundant at sites $2.5 \mathrm{~km}$ from the outfall (Sites 5 and 12; 3.0-3.2 $\times 10^{5}$ cells ml ${ }^{-1}$; Fig. 2q). Abundances of Prochlorococcus spp. varied from $2.4 \times 10^{4}$ to $6.4 \times$ $10^{4}$ cells ml-1, with no major changes observed over the sampling area (Fig. 2g). The abundance of picoeukaryotes ranged from $2.1 \times 10^{3}$ to $1.2 \times$ $10^{4}$ cells ml ${ }^{-1}$ (mean: $4.6 \times 10^{3}$ cells ml ${ }^{-1}$ ), and were also consistent across the sampling area (Fig. 2i).

\section{Microbial community phylogenetic diversity}

Alpha diversity indices of bacterial and archaeal OTUs based on SSU rRNA gene sequences showed some variability between the sites. The observed community richness, or number of observed OTUs, ranged between 225 and 357 OTUs, and richness at the outfall site fell near the middle of this range, at 291 (Fig. 3a). Two sites, Site 25 (9 km from outfall) and Site 6 (1.5 km from outfall), contained microbial communities of lower richness, at 225 and 240 OTUs, respectively. The Chao1 estimator of richness produced patterns similar to the observed richness (Fig. 3a,b), indicating that the depth of sequencing utilized was appropriate for the study. When the samples were organized by distance from the outfall, there appeared to be a potential increase in estimated richness with increasing distance to $\sim 5 \mathrm{~km}$. Again, Sites 6 and 25 had lower predicted richness 


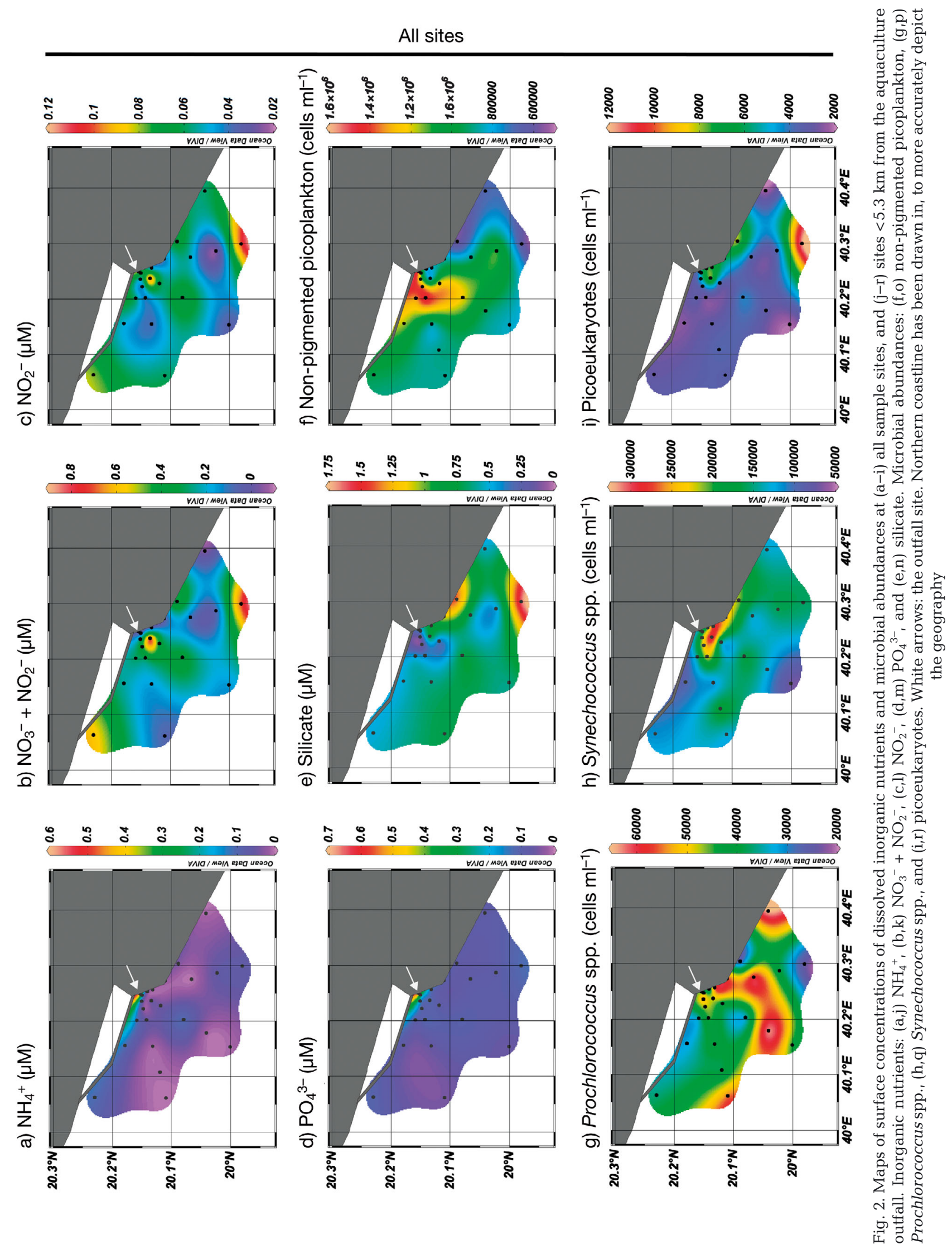




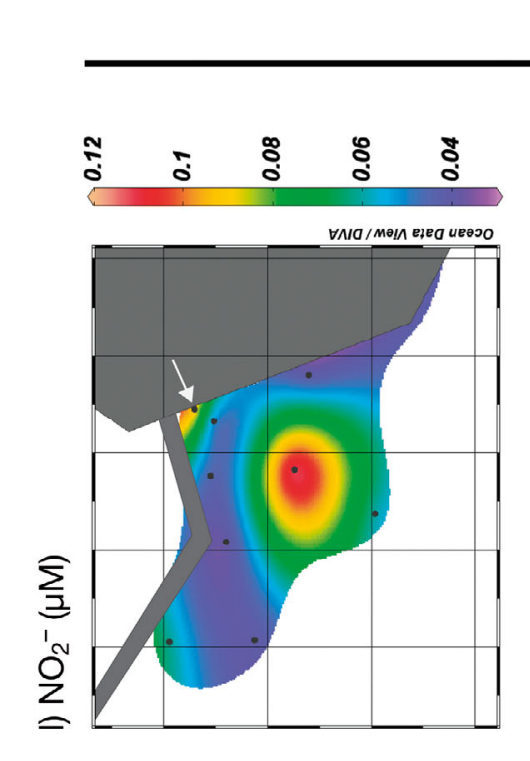

Sites nearest outfall
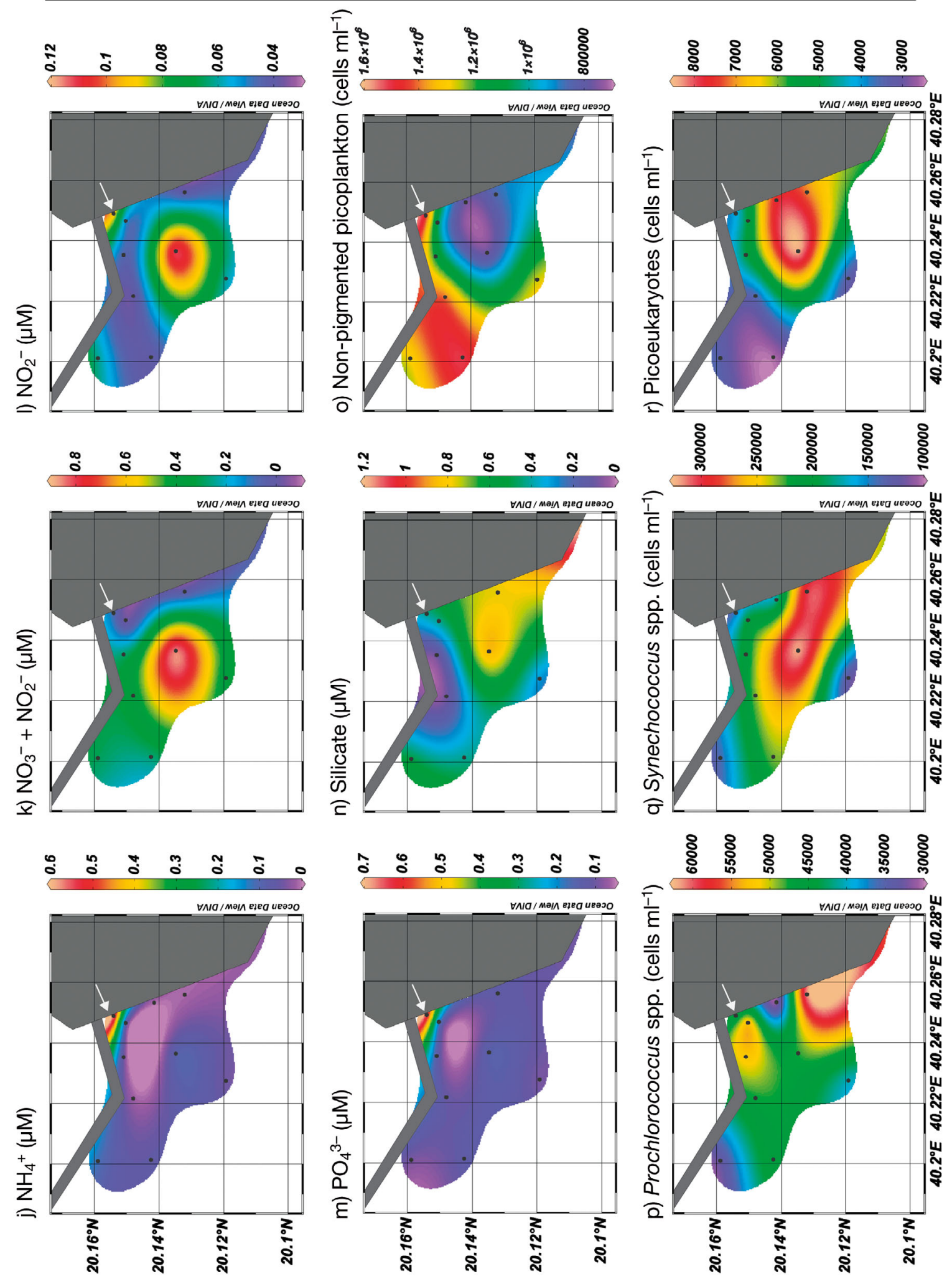

Fig. 2 (continued) 

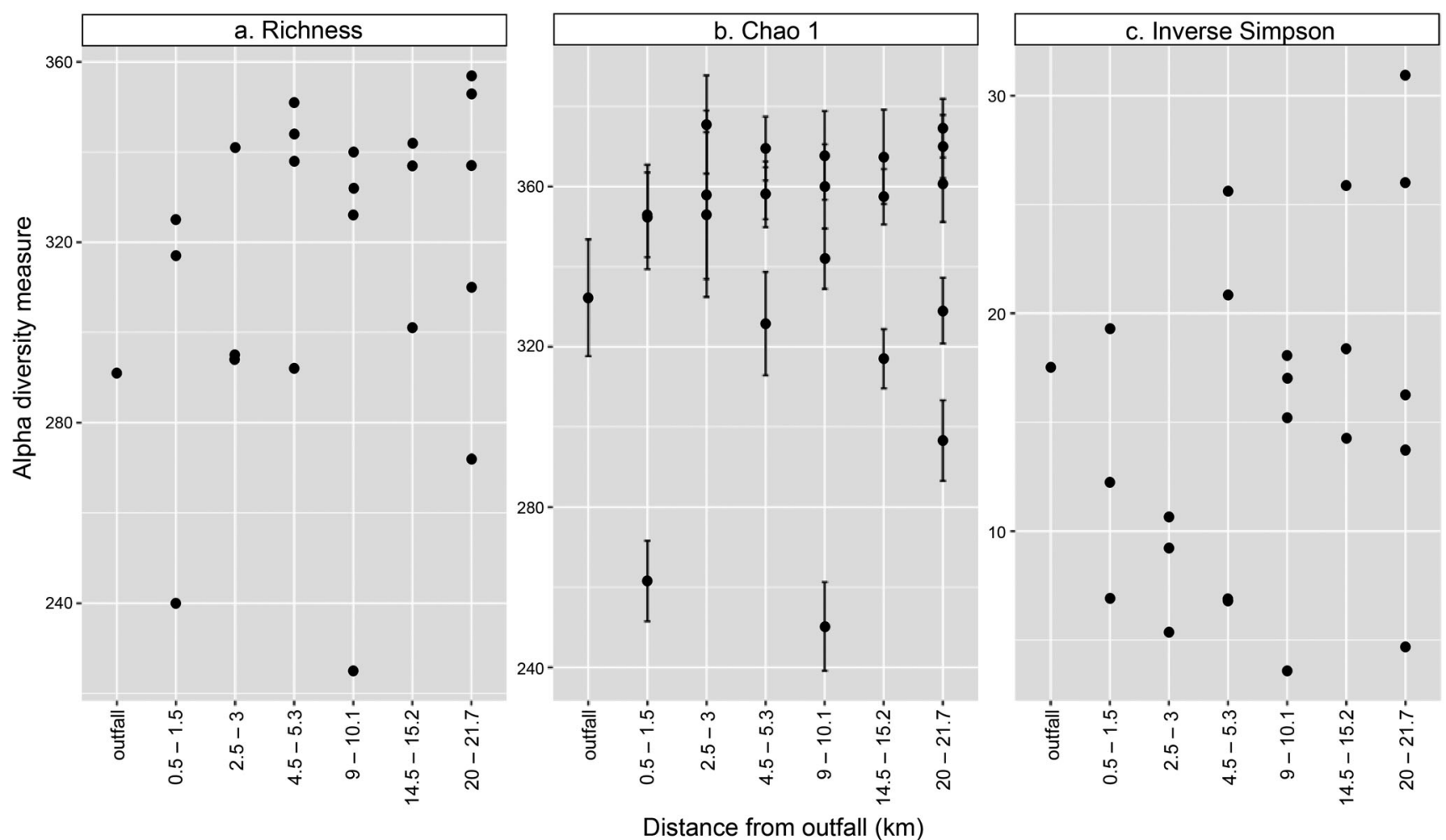

Fig. 3. Measures of alpha diversity based on bacterial and archaeal small subunit ribosomal RNA (SSU rRNA) genes at each sampling site: (a) community richness (e.g. number of operational taxonomic units), (b) Chao1 estimator (bars: $95 \%$ confidence intervals), and (c) inverse Simpson index. Data are organized into groups based on distance from the outfall

(Fig. 3b). The inverse Simpson index of diversity also indicates community evenness (Fig. 3c), and it ranged from low diversity and evenness, at 3.58 (Site $25,9 \mathrm{~km}$ from the outfall), to higher diversity and evenness, at 31 (Site 13, $20 \mathrm{~km}$ from the outfall), with a mean of 15. Even though Site 6 was low in both observed and estimated richness (Fig. 3a,b), it was not low in diversity relative to the other sites, indicating that Site 6 had a more even microbial community. In terms of diversity, the outfall, with an inverse Simpson index of 17.5, was similar to the other sites.

\section{Microbial community composition}

The SSU rRNA gene sequences were dominated by Cyanobacteria and Alphaproteobacteria and showed similar trends in composition across the sites (Fig. 4). Two sites, 24 and 25, were made up of mostly Cyanobacteria, comprising 60 and $75 \%$ of total sequences, respectively. The outfall (Site 8) was similar to most sites, except that it had 3 times as much Flavobacteria as all other sites (15.6\% compared to a mean of $4.7 \%$ for the other sites) (Fig. 4). An nMDS analysis provided a spatial representation of commu- nity composition resemblance between sites (Fig. 5). Again, in this analysis, the southern Sites 24 and 25 were separated from the group, supporting how microbial communities at these sites were distinct from most of the other sites. Coastal Site 6 was also separated, both from the entire group of sites, and also from the other sites $0.5-1.5 \mathrm{~km}$ (Fig. 5) from the outfall. In general, the arrangement of sites in the nMDS plot corresponds to actual distance from outfall, demonstrating that the bacterial and archaeal communities shifted in composition with increasing distance away from the effluent outfall. The $0.5-3 \mathrm{~km}$ group plotted closer to the outfall than the 4.5$10.1 \mathrm{~km}$ distance group. In addition, the 14.5$21.7 \mathrm{~km}$ group was even farther from the outfall point in the nMDS plot (Fig. 5). The outfall site is distinctly separate in the plot, indicating that there are taxa within the community that are unique to the outfall.

\section{Differentially abundant outfall bacteria}

Microbes indicative of the outfall effluent were examined using the SSU rRNA gene sequence count data, and 22 OTUs were significantly elevated or de- 


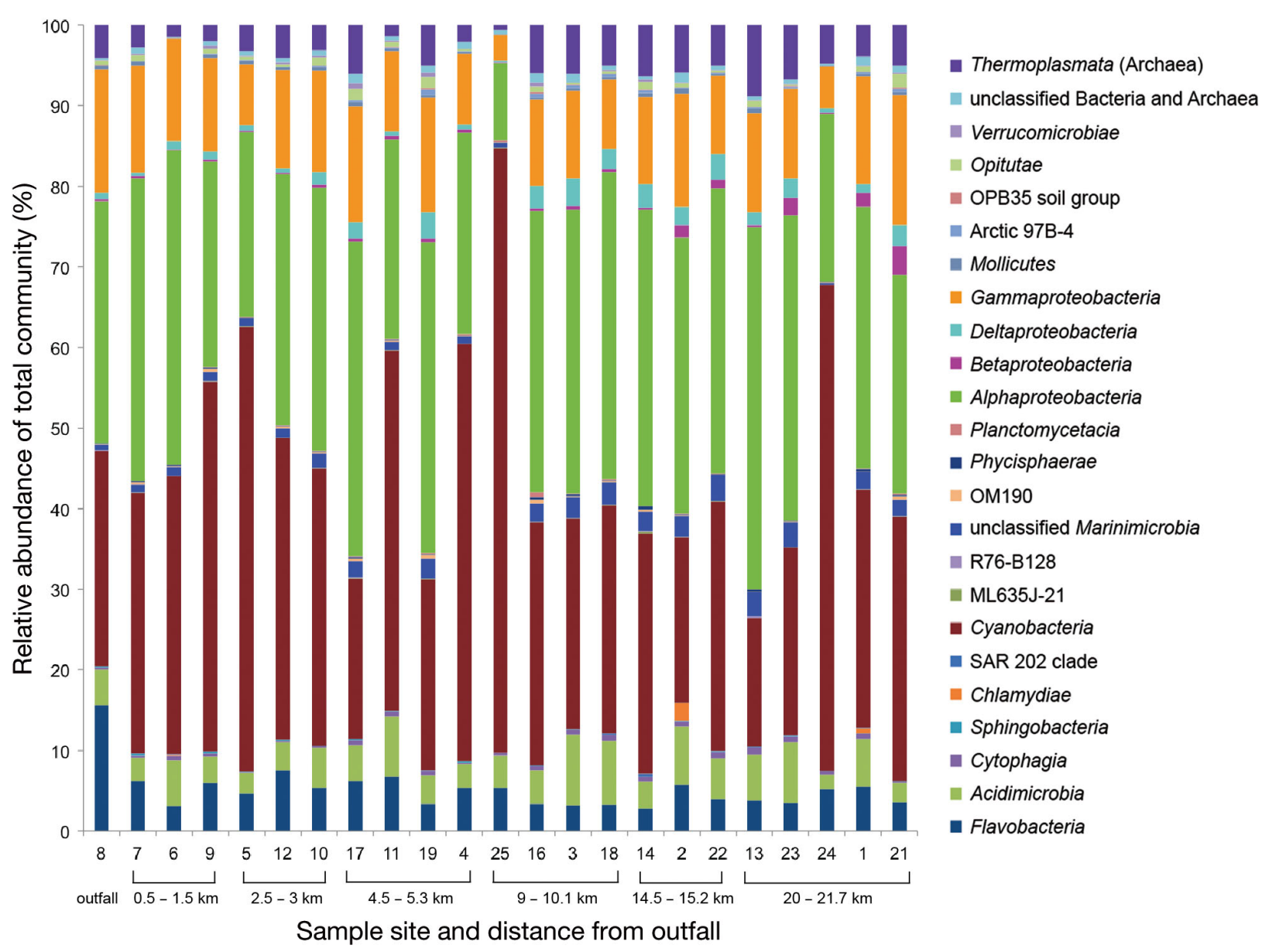

Fig. 4. Relative abundances of small subunit ribosomal RNA (SSU rRNA) gene sequences organized by taxonomic class for each site. Sites are organized by distance from outfall, with Sample 8 (outfall) on the far left and Sample 21 (21.7 km from Site 8) on the far right

pleted at the outfall when compared to the 6 distance groupings $(0.5-1.5,2.5-3,4.5-5.3,9-10.1,14.5-15.2$, and $20-21.7 \mathrm{~km}$ ) (Fig. 6, Table 1). Of these, 7 OTUs were significantly elevated at the outfall (Fig. 6). These included sequences classifying as Francisella spp., Caedibacter spp., uncultured Gammaproteobacteria, members of the NS4 Marine Group, uncultured Rickettsiales, uncultured Flavobacteriaceae, and uncultured Cryomorphaceae (Fig. 6a-g). Sequences of those OTUs enriched at the outfall were found in lower abundances at the more distant site groupings, and were significantly different at many of these groups $(\mathrm{p}<0.05$; Fig. 6 ). For OTUs 622 (Francisella spp.), 705 (Caedibacter spp.), and 1653 (uncultured Gammaproteobacteria), sequence counts were significantly lower at all distances compared to the outfall (Fig. 6a-C). Sequence counts for OTUs 1743 (NS4 Marine Group) and 1342 (uncultured Rickettsiales) were significantly lower at all distance groups except for the closest one, $0.5-1 \mathrm{~km}$ from the outfall

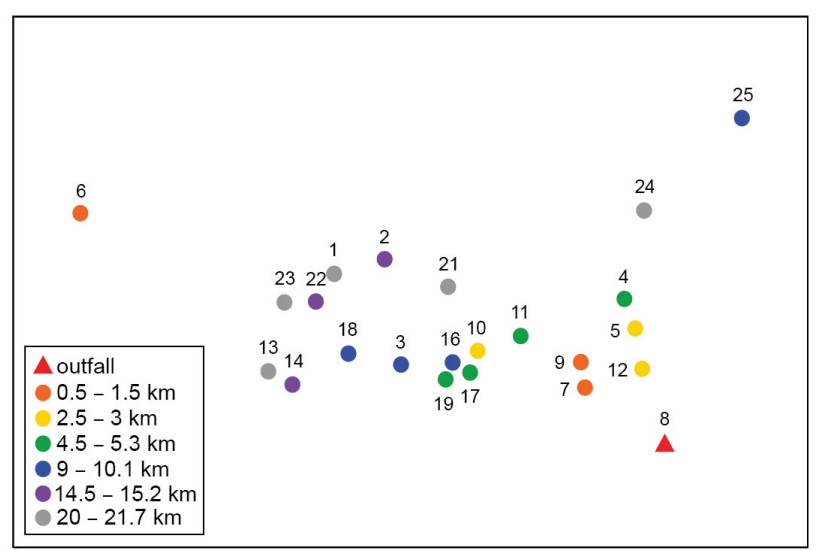

Fig. 5. Non-metric multidimensional scaling analysis of bacterial and archaeal community composition at each study site based on small subunit ribosomal RNA (SSU rRNA) gene sequences. Relative abundance data were square-root transformed and the resemblance of community composition was determined using Bray-Curtis similarity. Sites are grouped by distance from the outfall and the numbers indicate site. The 2-D stress of the solution is 0.06 

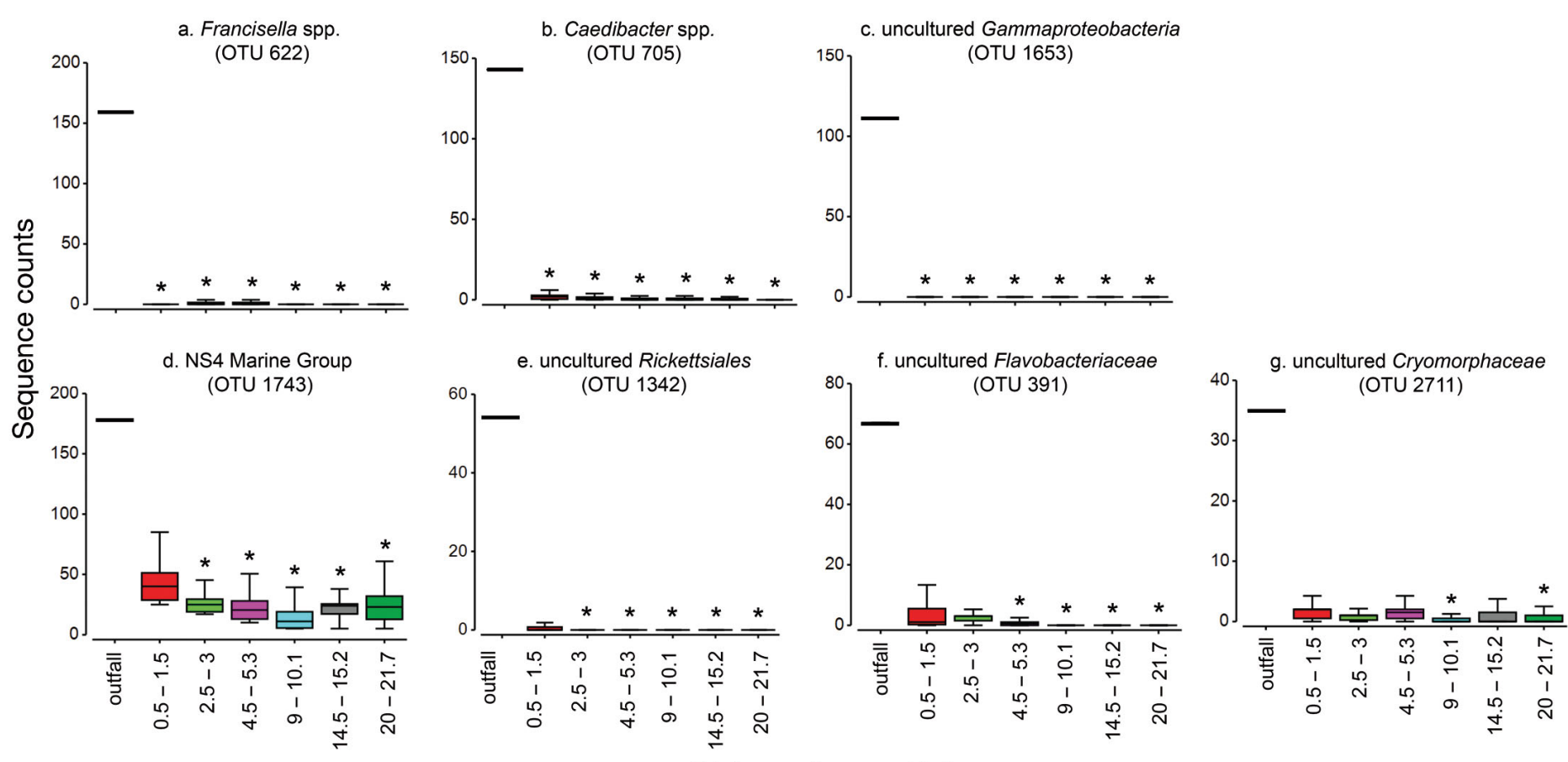

Fig. 6. Box-and-whisker plots of sequence counts for the 7 operational taxonomic units (OTUs) that were significantly enriched at the outfall site: (a) Francisella spp., (b) Caedibacter spp., (c) uncultured Gammaproteobacteria, (d) NS4 Marine Group, (e) uncultured Rickettsiales, (f) uncultured Flavobacteriaceae, and (g) uncultured Cryomorphaceae. * Distance groups with significantly depleted sequence counts compared to sequence counts at the outfall $(\mathrm{p}<0.05)$. The outfall includes 1 sample (indicated by single line) and the other distance groups include 3-5 samples. In each plot, middle line denotes median, box outlines upper and lower $25 \%$ quartiles, and whiskers denote maximum and minimum values

(Fig. 6d,e). Sequence counts for OTU 391 (uncultured Flavobacteriaceae) were significantly different from the outfall for the 4 farthest distance groups (4.5-5.3, $9-10.1,14.5-15.2$, and $20-21.7 \mathrm{~km})$, but not the 2 closest distance groups (Fig. 6f). Sequence counts for OTU 2711 (uncultured Cryomorphaceae) were significantly distinct from the outfall at 2 of the farther distance groups (9-10.1 and 20-21.7 km) (Fig. 6g). The other 15 significantly differentially abundant OTUs were significantly enriched or depleted in 3 or fewer distant groups, when compared to the outfall, as indicated by the positive and negative log2 fold change (Table 1). Out of the 15 significantly enriched OTUs, 11 were from the taxonomic class Flavobacteria (Table 1), the class of Bacteria found at higher relative abundance at the outfall compared to the other sites (Fig. 4).

\section{DISCUSSION}

This study analyzes multiple factors, including nutrient concentrations, microbial cell abundances, and the fine-scale taxonomy and composition of the bacterial and archaeal seawater communities, to examine the impact of an effluent point source from a large aquaculture facility on oligotrophic coral reefs within the Red Sea. Although our results represent data from 2009 and were collected prior to recent expansions of the facility, they show a distinct elevation of ammonium and phosphate and an altered microbial community structure at the outfall, with subtler differences within microbial community composition as distance from the outfall increases.

The elevated levels of ammonium and phosphate at the outfall site were consistent with findings of aquaculture impacts in other studies. Biao et al. (2004) found elevated inorganic nutrient concentrations, including ammonium and phosphorus, in a shrimp farm outlet creek that flowed from shrimp ponds to the Yellow Sea. In that study, changes in ammonium reached $4.7 \mu \mathrm{M}$, much greater than in our study, whereas the magnitude of change in inorganic phosphorus concentrations was $0.26 \mu \mathrm{M}$, lower than that measured in our study $(0.5 \mu \mathrm{M})$. In a study of fish cages in the eutrophic environment of the Xiangshan Bay, China, Xiong et al. (2015) observed overall increases in the concentrations of dissolved 


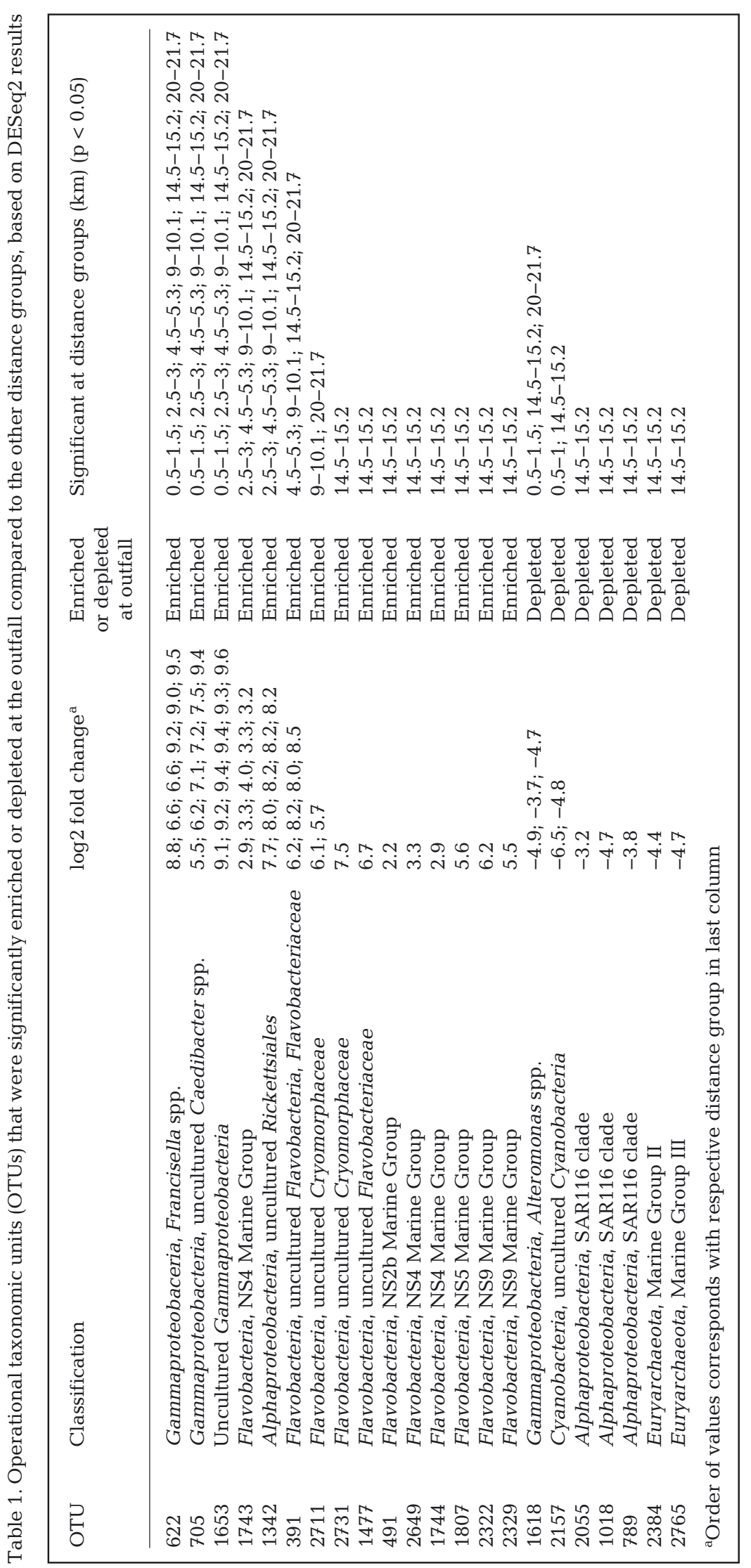

inorganic nitrogen and phosphate at fish cages relative to a reference site that was $8 \mathrm{~km}$ away. The magnitude of increase of dissolved inorganic nitrogen was approximately $2.4 \mu \mathrm{M}$, much higher than any concentration measured in our study. In contrast, while overall phosphate concentrations were higher within the eutrophic bay, the increase in phosphate at the fish farm $(0.1 \mu \mathrm{M})$ was lower than the increase measured in our study $(0.5 \mu \mathrm{M})$. Although the magnitude of changes varied among studies, the ubiquitous increase in seawater nutrient concentrations in areas supporting aquaculture facilities suggests that they can be a source of nutrient enrichment to both eutrophic and oligotrophic environments. This comparison further suggests that the elevated nutrient concentrations may be attributed to animal waste products generated at the aquaculture facility. Since the time of sampling in 2009, the Al Lith aquaculture facility has expanded considerably to include more shrimp farms and sea cages. If these inorganic nutrient concentrations were among the highest recorded in the Red Sea in 2009, we would hypothesize that nutrient levels will have only increased as a result of the expansions, further threatening the delicate reef ecosystem.

In the study presented here, we found it surprising that the effluent nutrient signal diminished so rapidly just $500 \mathrm{~m}$ away from the outfall. This could be related to the oligotrophic nature of the Red Sea waters, in which generally low-concentration or limiting nutrients are quickly mixed and diluted into the surrounding waters, or are rapidly assimilated by bacteria and other planktonic organisms that recycle these nutrients and incorporate them into microbial biomass. Although detailed circulation data for the Red Sea is scant, the study area features a buoyancy-driven boundary current that moves 
generally from south to north, which may also be contributing to the incorporation of nutrients into the surrounding waters (Eshel \& Naik 1997). Another factor may be the length of the effluent canal. Biao et al. (2004) found diminishing concentrations of all measured inorganic nutrients along an outlet canal that extended from 3 shrimp ponds to the Yellow Sea, over a distance of $11 \mathrm{~km}$. The effluent canal of the National Prawn Company facility runs the length of the shrimp pond area, over $20 \mathrm{~km}$ long, and may be acting as a potential biological buffer where higher levels of nutrients are consumed before reaching the oligotrophic waters.

Of the microbial cells enumerated, non-pigmented picoplankton were the only cell groups found to be elevated at the outfall, as well as at nearby sites. Non-pigmented picoplankton are primarily heterotrophic Bacteria and Archaea as well as nonpigmented photoheterotrophic Bacteria, and their abundance is often related to the organic carbon availability (Jumars et al. 1989), which was likely elevated as a result of shrimp organic wastes in the effluent. Although organic carbon was not measured here, preventing a complete assessment, a study of bacterial communities below a fish farm cage found increased abundances of heterotrophic bacteria as a result of total organic matter enrichment (La Rosa et al. 2004). This suggests the elevated abundances of non-pigmented picoplankton at the outfall may be due to populations of these cells residing in the organic-rich effluent, likely confirming the presence of increased organic matter. Indeed, future studies of aquaculture effluent should include quantification of particulate and dissolved organic carbon.

One particular strength of this study was the examination of the microbial SSU rRNA sequences from general bacterial and archaeal primers, which allowed for a more holistic examination of the communities compared to cultivation-dependent or indicator microbial assays, such as loop-mediated isothermal amplification assays that detect known bacterial pathogens (Zhou et al. 2014). An example of one of the benefits of using cultivation-independent techniques to study microbial communities within the environment is that it allowed us to produce new knowledge of potential indicator bacterial taxa that may be originating from shrimp aquaculture. We found alterations in the entire microbial community composition with increasing distance away from the aquaculture effluent point source. This finding is consistent with studies that found changes in the microbial communities between treated wastewater runoff and the seawater surrounding coral reefs in
Florida (Campbell et al. 2015) and in the Red Sea (Ziegler et al. 2016). It also confirms other study results that found alterations in bacterial communities in oligotrophic areas subject to aquaculture (fish farm) effluent (Garren et al. 2008, Fodelianakis et al. 2014). In our study, 22 groups of bacteria were identified as being significantly elevated or depleted at the outfall site. Of these, 7 were elevated at the outfall of the effluent canal when compared to multiple distances, suggesting that they potentially originated at the aquaculture facility. Of these enriched groups, 2 OTUs, classifying as Francisella spp. and uncultured Rickettsiales, are related to known pathogens. Francisella spp. have been implicated as pathogens for a wide taxonomic diversity of mammals and fish, as well as free-living cells (Sjödin et al. 2012). Pathogenic Francisella generally target marine organisms, causing disease in cod (Olsen et al. 2006), tilapia (Mauel et al. 2007), and giant abalone (Kamaishi et al. 2010). In addition, Francisella spp. can also impact a wide diversity of land mammals, including humans, through arthropod vectors or infected water (Pérez et al. 2016). It is likely that the infection breadth of Francisella spp. is highly underestimated (Birkbeck et al. 2011), and the significant occurrence of Francisella spp. at the shrimp aquaculture outfall may suggest that Francisella spp. originated in the shrimp ponds. Some pathogenic species, including F. noatunensis (cod pathogen) and F. tularensis (human pathogen), likely persist poorly in the environment without a host (Duodu \& Colquhoun 2010). Despite this, Francisella spp. have been isolated in seawater samples from around the world (Barns et al. 2005, Berrada \& Telford 2010, Duodu et al. 2012). Some pathogenic Francisella strains may interact with single-celled eukaryotes, allowing them to persist successfully in the environment (Verhoeven et al. 2010). While presence and abundance of singlecelled eukaryotes were not measured in this study, they generally feed on bacteria, and increased levels of heterotrophic bacteria at the effluent outfall may have provided a favorable environment for eukaryotic Francisella spp. hosts. The other putative pathogen detected in this study was uncultured Rickettsiales. While not every Rickettsiales bacterium is pathogenic, these bacteria belong to an order that is characterized by having both obligate intracellular and free-living lifestyles. Rickettsiales can invade arthropod hosts (Darby et al. 2007), and in fact, the first marine Rickettsiales pathogen to be characterized, 'Candidatus Hepatobacter penaei', was originally isolated from Penaeus vannamei, and subsequently found in both an arthropod and crustacean 
as well as a commonly cultured shrimp in the western hemisphere (Nunan et al. 2013). Caedibacter spp. encompass another interesting group of bacteria elevated at the outfall. While this bacterium is not pathogenic, this genus comprises species that are unique endosymbionts of paramecia (Beier et al. 2002). Paramecia have been isolated from fresh, brackish, and seawater environments where they can prey on other bacteria and algae (Fokin et al. 1999, Fokin 2010). While little information on specific associations of paramecia within shrimp aquaculture exist, the outfall of the effluent canal was characterized by increased counts of heterotrophic bacteria, and may have hosted an environment favorable to the algae- and bacteria-consuming paramecia, which could account for the increase in Caedibacter spp. at the outfall.

Other bacteria elevated at the outfall included common seawater bacteria, including uncultured Gammaproteobacteria, uncultured Flavobacteriaceae, NS4 Marine Group, and uncultured Cryomorphaceae. The Flavobacteriaceae are a large family of marine bacteria, and this family includes some species that are associated with phosphorus and nitrogen enrichment as well as shrimp aquaculture (Maeda et al. 2002, Abell \& Bowman 2005). NS4 Marine Group and uncultured Cryomorphaceae are also common bacteria in seawater, but less is known about their physiology (Alonso et al. 2007, Bowman 2014). While some bacteria were found at higher abundances at the outfall, others were significantly depleted at the outfall. For example, 3 OTUs belonging to the SAR116 clade of Alphaproteobacteria were depleted at the outfall. The SAR116 clade has been isolated from oligotrophic waters globally, such as the Sargasso Sea and the North Pacific Subtropical Gyre (Mullins et al. 1995, DeLong et al. 2006). While the Red Sea is naturally oligotrophic, the outfall site was characterized by nutrient enrichment. It is likely that the more eutrophic environment of the outfall was poorly suited for bacteria that thrive in oligotrophic waters, such as the SAR116 clade, but provided an ideal environment for other bacteria such as those from the class Flavobacteria and Francisella spp., as evidenced by the significant changes in sequence counts for those groups. In this way, the nutrient enrichment from the aquaculture facility appears to exert a bottom-up control on the microbial diversity near the effluent outfall.

Two limitations of this study included a lack of temporal resolution as well as site replication. These limitations prevented us from utilizing statistical approaches to compare the outfall nutrients and micro- bial cell abundances to the other sites. We were also not able to understand the consistency of the impact to the microbial communities over time, because one seawater sample was collected directly at the outfall. In the future, we recommend sampling farther up the effluent canal, or obtaining samples from the aquaculture pools to enhance our understanding of the microbial processes occurring within the effluent canal before the effluent reaches the Red Sea.

\section{CONCLUSIONS}

In our 2009 assessment of the impact of the National Aquaculture Group facility near Al Lith, Saudi Arabia on the microbial and biogeochemical composition of the eastern Red Sea, we found that the outfall site showed elevated concentrations of ammonium and phosphate, along with changes in the microbial communities, including the presence of the potential pathogens Francisella spp. and Rickettsiales. The impacts of the effluent were more localized than hypothesized, with elevated nutrients and statistically significant microbial community alterations restricted to only the outfall site and diminishing within $500 \mathrm{~m}$, likely related to the highly oligotrophic nature of these waters. Aside from this seemingly localized impact, we also noticed a shift in the microbial communities with increasing distance from the outfall across the entire study area. The impact of the aquaculture facility on the entire coral reef ecosystem was not addressed here, but our data for the waters overlying the reef near the effluent canal suggests that this ecosystem may indeed be impacted by the aquaculture effluent, and these reefs and their water quality should be monitored in the future. This study expands on the existing knowledge of the impacts aquaculture imposes on oligotrophic coral reef ecosystems, although since 2009, the increased aquaculture output in the eastern Red Sea may have altered the observed impacts. As the global aquaculture industry continues to expand to meet the demands of population growth, studies of this nature will be critical in order to assess the impacts that this industry imposes on the surrounding marine environment, especially in oligotrophic areas harboring sensitive coral reef ecosystems.

Acknowledgements. We thank Whitney Bernstein, Kathryn Furby, Jesse Kneeland and the crew of the M/V 'Dream Island' for sample collections and logistical support. We thank Karen Selph of the University of Hawai'i School of Ocean and Earth Science and Technology (SOEST) flow 
cytometry facility for cell counts, Joe Jennings of Oregon State University for inorganic nutrient analysis, and C. Wright and the University of Illinois W. M. Keck Center for Comparative and Functional Genomics for sequencing. This research was supported by a Woods Hole Oceanographic Institution (WHOI) Ocean Life Institute postdoctoral scholar fellowship to A.A., the Semester at WHOI Program supporting C.B., and Award No. USA 00002 to K.H. made by King Abdullah University of Science and Technology (KAUST).

\section{LITERATURE CITED}

Abell GCJ, Bowman JP (2005) Ecological and biogeographic relationships of class Flavobacteria in the Southern Ocean. FEMS Microbiol Ecol 51:265-277

Alonso C, Warnecke F, Amann R, Pernthaler J (2007) High local and global diversity of Flavobacteria in marine plankton. Environ Microbiol 9:1253-1266

Apprill A, Hughen K, Mincer TJ (2013) Major similarities in the bacterial communities associated with lesioned and healthy Fungiidae corals. Environ Microbiol 15:20632072

Apprill A, McNally S, Parsons R, Weber L (2015) Minor revision to V4 region SSU rRNA 806R gene primer greatly increases detection of SAR11 bacterioplankton. Aquat Microb Ecol 75:129-137

Apprill A, Weber L, Santoro A (2016) Distinguishing between microbial habitats unravels ecological complexity in coral microbiomes. mSystems 1:e00143-16

Armstrong FAJ, Stearns CR, Strickland JDH (1967) The measurement of upwelling and subsequent biological process by means of the Technicon Autoanalyzer ${ }^{\circledR}$ and associated equipment. Deep-Sea Res Oceanogr Abstr 14: 381-389

Barns SM, Grow CC, Okinaka RT, Keim P, Kuske CR (2005) Detection of diverse new Francisella-like bacteria in environmental samples. Appl Environ Microbiol 71: 5494-5500

Beier CL, Horn M, Michel R, Schweikert M, Gortz HD, Wagner M (2002) The genus Caedibacter comprises endosymbionts of Paramecium spp. related to the Rickettsiales (Alphaproteobacteria) and to Francisella tularensis (Gammaproteobacteria). Appl Environ Microbiol 68:6043-6050

Bernhardt H, Wilhelms A (1967) The continuous determination of low-level iron, soluble phosphate and total phosphate with the Autoanalyzer. In: Scova NB (ed) Technicon symposia, Vol 1. Mediad, New York, NY, p 385-389

*Berrada ZL, Telford SR (2010) Diversity of Francisella species in environmental samples from Martha's Vineyard, Massachusetts. Microb Ecol 59:277-283

Biao X, Zhuhong D, Xiaorong W (2004) Impact of the intensive shrimp farming on the water quality of the adjacent coastal creeks from Eastern China. Mar Pollut Bull 48: 543-553

Birkbeck TH, Feist SW, Verner-Jeffreys DW (2011) Francisella infections in fish and shellfish. J Fish Dis 34: 173-187

Bowman JP (2014) The family Cryomorphaceae. In: Rosenberg E, DeLong EF, Lory S, Stackebrandt E, Thompson F (eds) The prokaryotes. Springer, Berlin, p 539-550

Campbell AM, Fleisher J, Sinigalliano C, White JR, Lopez JV (2015) Dynamics of marine bacterial community diversity of the coastal waters of the reefs, inlets, and wastewater outfalls of southeast Florida. MicrobiologyOpen 4:390-408

Chen X, Wang K, Guo A, Dong Z, Zhao Q, Qian J, Zhang D (2016) Excess phosphate loading shifts bacterioplankton community composition in oligotrophic coastal water microcosms over time. J Exp Mar Biol Ecol 483:139-146

* Darby AC, Cho N, Fuxelius H, Westberg J, Andersson SGE (2007) Intracellular pathogens go extreme: genome evolution in the Rickettsiales. Trends Genet 23:511-520

* DeLong EF (2009) The microbial ocean from genomes to biomes. Nature 459:200-206

* DeLong EF, Preston CM, Mincer T, Rich V and others (2006) Community genomics among stratified microbial assemblages in the ocean's interior. Science 311:496-503

* Dong Z, Wang K, Chen X, Zhu J, Hu C, Zhang D (2017) Temporal dynamics of bacterioplankton communities in response to excessive nitrate loading in oligotrophic coastal water. Mar Pollut Bull 114:656-663

* dos Santos HF, Cury JC, do Carmo FL, dos Santos AL and others (2011) Mangrove bacterial diversity and the impact of oil contamination revealed by pyrosequencing: bacterial proxies for oil pollution. PLOS ONE 6:e16943

* Duodu S, Colquhoun D (2010) Monitoring the survival of fish-pathogenic Francisella in water microcosms. FEMS Microbiol Ecol 74:534-541

*Duodu S, Larsson P, Sjödin A, Forsman M, Colquhoun DJ (2012) The distribution of Francisella-like bacteria associated with coastal waters in Norway. Microb Ecol 64: 370-377

* Edgar RC, Haas BJ, Clemente JC, Quince C, Knight R (2011) UCHIME improves sensitivity and speed of chimera detection. Bioinformatics 27:2194-2200

Fren AM, Morrison HG, Lescault PJ, Reveillaud J, Vineis JH, Sogin ML (2015) Minimum entropy decomposition: unsupervised oligotyping for sensitive partitioning of high-throughput marker gene sequences. ISME J 9: 968-979

Eshel G, Naik NH (1997) Climatological coastal jet collision, intermediate water formation, and the general circulation of the Red Sea. J Phys Oceanogr 27:1233-1257

FAO (Food and Agriculture Organization of the United Nations) (2016) The state of the world fisheries and aquaculture 2016. FAO, Rome

Fodelianakis S, Papageorgiou N, Pitta P, Kasapidis P, Karakassis I, Ladoukakis ED (2014) The pattern of change in the abundances of specific bacterioplankton groups is consistent across different nutrient-enriched habitats in Crete. Appl Environ Microbiol 80:3784-3792

Fokin SI (2010) Paramecium genus: biodiversity, some morphological features and the key to the main morphospecies discrimination. Protistology 6:227-235

Fokin S, Stoeck T, Schmidt H (1999) Paramecium duboscqui Chatton, Brachon, 1933. Distribution, ecology and taxonomy. Eur J Protistol 35:161-167

*Furby KA, Apprill A, Cervino JM, Ossolinski JE, Hughen KA (2014) Incidence of lesions on Fungiidae corals in the eastern Red Sea is related to water temperature and coastal pollution. Mar Environ Res 98:29-38

Garren M, Smriga S, Azam F (2008) Gradients of coastal fish farm effluents and their effect on coral reef microbes. Environ Microbiol 10:2299-2312

* Garren M, Raymundo L, Guest J, Harvell CD, Azam F (2009) Resilience of coral-associated bacterial communities exposed to fish farm effluent. PLOS ONE 4:e7319

Hambrey JB (2009) Global review and synthesis of reviews 
of EIA and monitoring in aquaculture in four regions and for salmon aquaculture. In: Barg U, Soto D, AguilarManjarrez J, Hambrey J, Castilla JL (eds). Environmental impact assessment and monitoring in aquaculture. FAO Fish Aquacult Tech Pap No. 527. FAO, Rome, p 3-57

Kernández E, Figueroa J, Iregui C (2009) Streptococcosis on a red tilapia, Orechromis sp., farm: a case study. J Fish Dis 32:247-252

Holmes RM, Aminot A, Kérouel R, Hooker BA, Peterson BJ (1999) A simple and precise method for measuring ammonium in marine and freshwater ecosystems. Can J Fish Aquat Sci 56:1801-1808

Jiang Z, Liao Y, Liu J, Shou L and others (2013) Effects of fish farming on phytoplankton community under the thermal stress caused by a power plant in a eutrophic, semienclosed bay: induce toxic dinoflagellate (Prorocentrum minimum) blooms in cold seasons. Mar Pollut Bull 76: 315-324

Jumars PA, Penry DL, Baross JA, Perry MJ, Frost BW (1989) Closing the microbial loop: dissolved carbon pathway to heterotrophic bacteria from incomplete ingestion, digestion and absorption in animals. Deep-Sea Res A 36: 483-495

Kamaishi T, Miwa S, Goto E, Matsuyama T, Oseko N (2010) Mass mortality of giant abalone Haliotis gigantea caused by a Francisella sp. bacterium. Dis Aquat Org 89:145-154

Kirchman DL, Elifantz H, Dittel AI, Malmstrom RR, Cottrell MT (2007) Standing stocks and activity of Archaea and Bacteria in the western Arctic Ocean. Limnol Oceanogr 52:495-507

Kozich JJ, Westcott SL, Baxter NT, Highlander SK, Schloss PD (2013) Development of a dual-index sequencing strategy and curation pipeline for analyzing amplicon sequence data on the MiSeq Illumina sequencing platform. Appl Environ Microbiol 79:5112-5120

* La Rosa T, Mirto S, Mazzola A, Maugeri TL (2004) Benthic microbial indicators of fish farm impact in a coastal area of the Tyrrhenian Sea. Aquaculture 230:153-167

Love MI, Huber W, Anders S (2014) Moderated estimation of fold change and dispersion for RNA-seq data with DESeq2. Genome Biol 15:550

Loya Y, Lubinevsky H, Rosenfeld M, Kramarsky-Winter E (2004) Nutrient enrichment caused by in situ fish farms at Eilat, Red Sea is detrimental to coral reproduction. Mar Pollut Bull 49:344-353

Maeda M, Nogami K, Kanematsu S, Kotani Y (2002) Manipulation of microbial communities for improving the aquaculture environment. US-Japan Cooperative Program in Natural Resources (UJNR) Tech Rep 24:125-130

Mauel MJ, Soto E, Moralis JA, Hawke J (2007) A Piscirickettsiosis-like syndrome in cultured Nile tilapia in Latin America with Francisella spp. as the pathogenic agent. J Aquat Anim Health 19:27-34

McMurdie PJ, Holmes S (2013) phyloseq: an R package for reproducible interactive analysis and graphics of microbiome census data. PLOS ONE 8:e61217

Mon Chalil G (2015) The new investment wave into aquaculture in Middle East countries: opportunities and challenges. FAO, Rome. www.fao.org/in-action/globefish/ fishery-information/resource-detail/en/c/338614/

Mullins TD, Britschgi TB, Krest RL, Giovannoni SJ (1995) Genetic comparisons reveal the same unknown bacterial lineages in Atlantic and Pacific bacterioplankton communities. Limnol Oceanogr 40:148-158
Naylor RL, Goldburg RJ, Primavera JH, Kautsky N and others (2000) Effect of aquaculture on world fish supplies. Nature 405:1017-1024

*Nogales B, Lanfranconi MP, Piña-Villalonga JM, Bosch R (2011) Anthropogenic perturbations in marine microbial communities. FEMS Microbiol Rev 35:275-298

Nunan LM, Pantoja CR, Gomez-Jimenez S, Lightner DV (2013) 'Candidatus Hepatobacter penaei,' an intracellular pathogenic enteric bacterium in the hepatopancreas of the marine shrimp Penaeus vannamei (Crustacea: Decapoda). Appl Environ Microbiol 79:1407-1409

* Olsen AB, Mikalsen J, Rode M, Alfjorden A and others (2006) A novel systemic granulomatous inflammatory disease in farmed Atlantic cod, Gadus morhua L., associated with a bacterium belonging to the genus Francisella. J Fish Dis 29:307-311

* Pérez N, Johnson R, Sen B, Ramakrishnan G (2016) Two parallel pathways for ferric and ferrous iron acquisition support growth and virulence of the intracellular pathogen Francisella tularensis Schu S4. MicrobiologyOpen 5: 453-468

Fantoro AE, Casciotti KL, Francis CA (2010) Activity, abundance and diversity of nitrifying archaea and bacteria in the central California Current. Environ Microbiol 12: 1989-2006

Schlitzer R (2002) Interactive analysis and visualization of geoscience data with Ocean Data View. Comput Geosci 28:1211-1218

Schloss PD, Westcott SL, Ryabin T, Hall JR and others (2009) Introducing mothur: open-source, platform-independent, community-supported software for describing and comparing microbial communities. Appl Environ Microbiol 75:7537-7541

* Sjödin A, Svensson K, Öhrman C, Ahlinder J and others (2012) Genome characterisation of the genus Francisella reveals insight into similar evolutionary paths in pathogens of mammals and fish. BMC Genomics 13:268

* Sousa OV, Macrae A, Menezes FGR, Gomes NCM, Vieira RHSF, Mendonça-Hagler LCS (2006) The impact of shrimp farming effluent on bacterial communities in mangrove waters, Ceará, Brazil. Mar Pollut Bull 52: 1725-1734

USEPA (US Environmental Protection Agency) (1983) Nitrogen, ammonia. Method 350.1 (colorimetric, automated, phenate). In: Methods for chemical analysis of water and wastes. USEPA, Cincinnati, OH, p 350.1-1 - 350.1-4

*Verhoeven AB, Durham-colleran MW, Pierson T, Boswell WT, Van Hoek ML (2010) Francisella philomiragia biofilm formation and interaction with the aquatic protist Acanthamoeba castellanii. Biol Bull (Woods Hole) 219: 178-188

Villanueva RD, Yap HT, Montaño MNE (2005) Survivorship of coral juveniles in a fish farm environment. Mar Pollut Bull 51:580-589

WWei C, Zeng Y, Tang K, Jiao N (2009) Comparison of bacterioplankton communities in three mariculture ponds farming different commercial animals in subtropical Chinese coast. Hydrobiologia 632:107-126

Wickham H (2009) Ggplot2: elegant graphics for data analysis. Springer, New York, NY

* Xiong J, Chen H, Hu C, Ye X, Kong D, Zhang D (2015) Evidence of bacterioplankton community adaptation in response to long-term mariculture disturbance. Sci Rep 5:15274

K Zhou Q, Wang L, Chen J, Wang R and others (2014) Devel- 
opment and evaluation of a real-time fluorogenic loopmediated isothermal amplification assay integrated on a microfluidic disc chip (on-chip LAMP) for rapid and simultaneous detection of ten pathogenic bacteria in aquatic animals. J Microbiol Methods 104:26-35
Ziegler M, Roik A, Porter A, Zubier K, Mudarris MS, Ormond R, Voolstra CR (2016) Coral microbial community dynamics in response to anthropogenic impacts near a major city in the central Red Sea. Mar Pollut Bull 105: $629-640$

APPENDIX

Table A1. Summary of sampling sites, sequence reads, and alpha diversity metrics. MED: minimum entropy decomposition, na: not applicable, OTU: operational taxonomic unit

\begin{tabular}{|c|c|c|c|c|c|c|c|}
\hline $\begin{array}{l}\text { Sample } \\
\text { site }\end{array}$ & $\begin{array}{l}\text { Distance } \\
\text { to outfall } \\
(\mathrm{km})\end{array}$ & $\begin{array}{l}\text { No. of } \\
\text { reads }\end{array}$ & $\begin{array}{l}\text { Sub- } \\
\text { sampled } \\
\text { reads }\end{array}$ & $\begin{array}{l}\text { No. of } \\
\text { reads after } \\
\text { MED }\end{array}$ & $\begin{array}{l}\text { No. of } \\
\text { OTUs }\end{array}$ & Chao1 & $\begin{array}{l}\text { Inverse } \\
\text { Simpson }\end{array}$ \\
\hline 8 & 0 & 23149 & 10200 & 9059 & 291 & 332 & 17.5 \\
\hline 7 & $0.5 \mathrm{~W}$ & 27653 & 10200 & 9132 & 317 & 352 & 12.3 \\
\hline 6 & $1.5 \mathrm{~S}$ & 15503 & 10200 & 8853 & 240 & 262 & 19.3 \\
\hline 9 & $1.5 \mathrm{~N}$ & 34380 & 10200 & 9473 & 325 & 353 & 6.92 \\
\hline 5 & $2.5 \mathrm{~S}$ & 30509 & 10200 & 9538 & 295 & 358 & 5.35 \\
\hline 12 & $2.5 \mathrm{SW}$ & 23761 & 10200 & 9161 & 294 & 353 & 9.23 \\
\hline 10 & 3 NW & 18933 & 10200 & 9369 & 341 & 375 & 10.7 \\
\hline 17 & $4.5 \mathrm{SW}$ & 19276 & 10200 & 9025 & 351 & 370 & 25.7 \\
\hline 11 & $5 \mathrm{NW}$ & 27524 & 10200 & 9406 & 338 & 358 & 6.91 \\
\hline 19 & $5 \mathrm{~N}$ & 16656 & 10200 & 9075 & 344 & 358 & 20.9 \\
\hline 4 & $5.3 \mathrm{~S}$ & 15755 & 10200 & 9327 & 292 & 326 & 6.80 \\
\hline 25 & $9 \mathrm{~S}$ & 18132 & 10200 & 9205 & 225 & 250 & 3.58 \\
\hline 16 & $9.5 \mathrm{SW}$ & 23822 & 10200 & 9115 & 326 & 342 & 15.2 \\
\hline 3 & $10 \mathrm{~S}$ & 27600 & 10200 & 9336 & 332 & 360 & 18.1 \\
\hline 18 & 10.1 NW & 28537 & 10200 & 9035 & 340 & 369 & 17.1 \\
\hline $20^{\mathrm{a}}$ & $10.7 \mathrm{~N}$ & 266 & na & na & na & na & na \\
\hline 14 & $14.5 \mathrm{SW}$ & 24107 & 10200 & 9258 & 301 & 317 & 18.4 \\
\hline 2 & $15 \mathrm{~S}$ & 33282 & 10200 & 9000 & 342 & 357 & 25.9 \\
\hline 22 & 15.2 NW & 34679 & 10200 & 8908 & 337 & 367 & 14.3 \\
\hline 13 & $20 \mathrm{SW}$ & 22209 & 10200 & 9157 & 310 & 329 & 31.0 \\
\hline 23 & 20.3 NW & 55182 & 10200 & 9032 & 337 & 361 & 26.1 \\
\hline 24 & $20.5 \mathrm{~S}$ & 10200 & 10200 & 9365 & 272 & 297 & 4.68 \\
\hline 1 & $21.5 \mathrm{~S}$ & 24170 & 10200 & 8894 & 353 & 370 & 16.3 \\
\hline 21 & $21.7 \mathrm{~N}$ & 45407 & 10200 & 8881 & 357 & 375 & 13.8 \\
\hline
\end{tabular}

Editorial responsibility: Pablo Sánchez Jerez, Alicante, Spain
Submitted: February 13, 2017; Accepted: July 10, 2017

Proofs received from author(s): September 5, 2017 